\title{
Bioremediation of 3,5-dinitrobenzoic acid and aniline by a Corynebacterium sp.
}

\author{
Ahmed, Y. M. ${ }^{1,3 *}$, Kumosani, T. A. ${ }^{1}$ and Sabir, J. S. M. ${ }^{2}$ \\ ${ }^{1}$ Biochemstry Department, Faculty of Science, King Abdulaziz University, Jeddah, Saudi Arabia \\ ${ }^{2}$ Biolgy Department, Faculty of Science, King Abdulaziz University, Jeddah, Saudi Arabia \\ ${ }^{3}$ National Research Center, Microbial Biotechnology Department, Egypt.
}

Accepted 25 June, 2013

\begin{abstract}
Corynebacterium sp was isolated from the soil by using 3-5 dinitro benzoic acid (DNB) as a sole carbon source. The highest rate of degradation of aniline (AN) or DNB was found in the exponential phase of the growth of the bacterium. After $24 \mathrm{~h}$, about $50 \%$ of DNB and $30 \%$ of AN were degraded by Corynebacterium sp. At a concentration of 0.5 to $1 \mathrm{~g} / \mathrm{L}$ of AN or DNB, good growth was obtained and the protocatechuic acid was detected. The optimum concentration of yeast extract was $2 \mathrm{~g} / \mathrm{l}$. Catechol 1-2 dioxygenase was induced in the cells grown on a medium containing AN or DNB. A significant activity of this enzyme was detected, which means that ortho cleavage pathway may be present in Corynebacterium sp.
\end{abstract}

Key words: Corynebacterium sp., degradation, dinitrobenzoic acid (DNB), aniline (AN), protocatechuic acid, catechol, catechol 1-2 dioxygenase, Ortho cleavage, high performance liquid chromatography (HPLC).

\section{INTRODUCTION}

Majority of organic compound residues cause environmental hazards. Nitroaromatics and aniline are toxic chemicals present in the effluent of many industries as they are widely used as raw materials in the manufacturing of a number of products such as dyes, plastics, resins, pharmaceuticals, petro-chemicals, herbicides, pesticides among others. (Nishino and Spain, 2004, 2006; Peres and Agathos, 2000).

Many nitroaromatics have been shown to be toxic or mutagenic to many bacteria, yeasts, fungi, unicellular algae, todepool copepods and oyster larvae (Won et al. 1976; Marvin-Sikkema and de Bont, 1994). However, some bacteria such as Pseudomonas sp. strain JS42 (Haigler et al., 1994), Pseudomonas putida OU83 (Walia et al., 2003) and Micrococcus sp. (Mulla et al., 2011) could use 2-nitrotoluene as a sole source of carbon. Samanta et al. (2000) isolated Ralstonias sp. SL 98 by chemotactic enrichment technique. This organism is capa- ble of utilizing different nitroaromatic compounds. Bengtsson and Carlsson (2001) isolated bacteria from pristine groundwater that degraded aniline in a slow rate. Liu et al. (2002) isolated a bacterial strain, AN3, which was able to use aniline or acotanilide as sole carbon and nitrogen sources from activated sludge and identified it as Delftiasp. AN3. This strain was capable of growing in concentrations of aniline up to $5000 \mathrm{mg} / \mathrm{l}$.

Corynebacterium glutamicum has been used as a model bacterium for fermentative production of various amino acids and vitamins. The knowledge of aromatic degradation and assimilation by this bacterium had been rarely explored until recently (Shen et al., 2012). C. glutamicum grows on the following aromatic compounds: benzoate, phenol (Shen et al., 2004), 3-hydrobenzoate, gentisate (Shen et al., 2005), resorcinol (Huang et al., 2006) and naphthalene (Lee et al., 2010).

This paper focuses on the characterization of 
Corynebacterium sp isolated from the Egyptian soil which is able to grow on dinitrobenzene and aniline and also detects the cleavage pathway of these compounds.

\section{MATERIALS AND METHODS}

Microorganism

\section{Isolation and characterization}

A strain was isolated from soil of Tahwhay-Monifia (Egypt), using 35 dinitro benzoic acid (DNB) as a sole carbon source. The soil sample $(10 \mathrm{~g} / \mathrm{l})$ was suspended in $100 \mathrm{ml}$ MSM media supplemented with $4 \mathrm{~g} / \mathrm{l}$ (DNB) in $250 \mathrm{ml}$ Erlenmeyer flasks on shaker at $120 \mathrm{rpm}$ and $30^{\circ} \mathrm{C}$. It was sub-cultured for 7 days until the growth was evidenced by increasing turbidity. Bacterial strains in the degrading culture were purified by repetitive streaking onto minimal salt medium (MSM); $1 \mathrm{~g} / \mathrm{l}$ DNB was added as sole carbon source and pure colony was obtained after 6 days.

Diagnostic tests for the morphological and physiological studies were carried out according to the "Bergery's Manual of Determinative Bacteriology," $7^{\text {th }}$ Ed. (1957) and Lechevaller et al. (1980).

\section{Media}

Minimal salt medium (MSM)

MSM medium with $20 \mathrm{~g} / \mathrm{l}$ agar was used to test the growth of bacterium on each phenol $(\mathrm{Ph})$, bromobenzene $(\mathrm{BrB})$, salicylate (Sal), benzoate (Ben) or gallic acid $(\mathrm{GaA})$ as sole carbon source. Phenol (Ph), bromobezene (BrB), salicylic (Sal), benzoate (Ben) and galic acid $(\mathrm{GaA})$ were sterilized by filtration and were added as sole carbon source $(1 \mathrm{~g} / \mathrm{l})$.

The minimal salt medium (MSM) consisted of the following component: $\mathrm{g} / \mathrm{l}$ tap water, $1 ; \mathrm{KH}_{2} \mathrm{PO}_{4}, 0.6 ; \mathrm{K}_{2} \mathrm{HPO}_{4}, 1 ;(\mathrm{NH})_{2} \mathrm{SO}_{4}$, $0.5 \mathrm{MgSO}_{4} .7 \mathrm{H}_{2} \mathrm{O}$. The medium $\mathrm{pH}$ was adjusted to $\mathrm{pH} 7-7.5$ by $\mathrm{NaOH}(1 \mathrm{~N})$.

\section{Maintenance medium}

The same MSM medium containing $20 \mathrm{~g} / \mathrm{l}$ agar was used in case of plate technique for bacterial isolation. To maintain the bacterial strain $2 \mathrm{~g} / \mathrm{l}$ yeast extract was added to this medium.

\section{Fermentation medium}

The growth medium contained the following: $1.5 \mathrm{~g} ; \mathrm{KH}_{2} \mathrm{PO}_{4}, 1.0 \mathrm{~g}$; $\mathrm{K}_{2} \mathrm{HPO}_{4}, 2.0 \mathrm{~g} ;(\mathrm{NH})_{2} \mathrm{SO}_{4}, 0.5 \mathrm{~g} ; \mathrm{MgSO}_{4} .7 \mathrm{H}_{2} \mathrm{O}, 5 \mathrm{mg}$; $\mathrm{FeSO}_{4} .4 \mathrm{H}_{2} \mathrm{O}$ and $2 \mathrm{~g}$, yeast extract in tap water $(1 \mathrm{~L})$. The medium $\mathrm{pH}$ was adjusted to $\mathrm{pH} 7-7.5$ by $\mathrm{NaOH}(1 \mathrm{~N})$. DNB and AN were sterilized by filtration and were added as sole carbon sources at 1 $\mathrm{g} / \mathrm{L}$. Twenty-five milliliter $(25 \mathrm{ml})$ of the growth medium was added to Erlenmeyer flasks $(250 \mathrm{ml})$ on shaker at $120 \mathrm{rpm}$ and $30^{\circ} \mathrm{C}$ for two days.

\section{Analytical methods}

\section{Growth determination}

The growth of cells was determined by measuring the absorbance at $600 \mathrm{~nm}$ spectrophotometrically (Shimadzu 24016), according to the methods of Puntus et al. (1997). Absorbency was converted to dry weight by using a standard curve.

\section{Metabolite formation}

Utilization of aromatic compounds by whole cells was monitored by spectrophotometrically scanning the culture medium in the UV range (Sutherland et al., 1981).

\section{High performance liquid chromatography (HPLC)}

HPLC analysis was carried out with Schimadzu HPLC LC10. The samples were analyzed by separation on Shim pack-CLCODSCM $(4.6 \times 150 \mathrm{~nm})$ using methanol as the mobile phase, at a flow rate of $1 \mathrm{ml} / \mathrm{min}$ at room temperature. DNA, aniline and fermentation products eluted out were detected with a UV detector at $254 \mathrm{~nm}$.

\section{Extraction of enzyme}

Exponentially, growing cells were harvested by centrifugation at $5000 \mathrm{rpm}$ for $20 \mathrm{~min}$ under cooling at $10^{\circ} \mathrm{C}$. The cells were washed in $20 \mathrm{ml}$ of chilled $20 \mathrm{mM}$ Tris-HCl buffer, $\mathrm{pH} 7.5$ and centrifuged as usual. The pellets were re-suspended in $5 \mathrm{ml}$ of the same buffer and frozen. The frozen cell suspensions were thawed and sonically disrupted for 7 min with Gallen Kamp (24 Amp) Germany. The probe was pre-chilled and samples cooled in water during sonic treatment. The extract was centrifuged at $5000 \mathrm{rpm}$ for $20 \mathrm{~min}$.

Total proteins in the clear dark yellow cell-free extracts were determined by the method of Lowry et al. (1951). Bovine serum albumin (Sigma, Fraction V) was used as a standard.

\section{Enzyme assays}

\section{Catechol 2,3-dioxygenase activity}

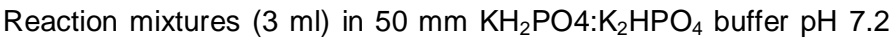
containing $1 \mathrm{mmol}$ catechol were equilibrated at $55^{\circ} \mathrm{C}$ before adding the cell extract $(100 \mathrm{ml})$. The increase in absorbance at $375 \mathrm{~nm}$ caused by the formations of the reaction product 2-hydroxymuconic semialdehyde was monitored. (Asturias and Timmis, 1993).

\section{Catechol 1,2-dioxygenase activity}

Reaction conditions were identical to those of the catechol-2,3dioxygenase assay except the formation of cis, cis-muconic acid which was monitored at $260 \mathrm{~nm}$ (Dorn and Knackmuss, 1978). One unit of enzyme activity was defined as the amount of enzyme that catalyzed the formation of $1 \mu \mathrm{mol}$ of product per $\min$ in $1 \mathrm{ml}$ reaction mixture. Specific activities were expressed as units per mg of protein.

\section{RESULTS AND DISCUSSION}

\section{Isolation of the microorganism from the soil}

Different carbon sources such as phenol (Ph), bromobenzene $(\mathrm{BrB})$, salicylate (Sal), benzoate (Ben), gallic acid $(\mathrm{GaA})$, aniline (AN) and DNB at concentration of $1 \mathrm{~g} / \mathrm{l}$ each were added to agar MSM at $30^{\circ} \mathrm{C}$. It was found that the isolated strains assimilate $\mathrm{Ph}, \mathrm{BrB}$, Sal, 
Table 1. Taxonomical studies of strain.

\begin{tabular}{ll}
\hline No. & Cell morphology \\
\hline A. & Short rods- occurring in pairs, also singly and irregular masses. \\
& Gram-positive. Non-motile . Non- sporulating, Not acid-fast. \\
B. & Cultural profiles \\
1 & Nutrient agar colony: moderate growth, circular, smooth, slightly elevated \\
2 & Nutrient agar slant : moderate growth, filiform, opaque \\
3 & Nutrient broth: slightly to moderately turbid, flocculent sediment. \\
C. & Physiological characteristics \\
1 & Optimum temperature, 25 to $37^{\circ} \mathrm{C}$, faint growth at $45^{\circ} \mathrm{C}$. \\
2 & Optimum pH 7-8; range $6-9$ \\
$3-$ & Not heat tolerant \\
$4-$ & Aerobic to facultative anaerobic \\
5 & Gelatin not liquefied. \\
6 & Litmus milk: no change or slightly alkaline \\
7 & Starch not hydrolyzed. \\
8 & Fermentative glucose \\
9 & Casein not dissimilated \\
10 & Catalase: positive \\
11 & Oxidase: positive \\
12 & Phosphatase: negative \\
13 & Methylene blue reduced \\
\hline
\end{tabular}

Ben, GaA, AN and DNB. Good growth was found in the case of AN and DNB as carbon source.

\section{Taxonomical studies of the strain}

The results of taxonomical studies are shown in Table 1. Based on the tests used in the $7^{\text {th }}$ edition of " Bergery's Manual of Determinative bacteriology," and Lechevaller et al. (1980), the strain was identified as Corynebacterium sp.

\section{Degradation of DNB or AN in shaking flasks}

$1 \mathrm{~g} / \mathrm{L}$ of DNB or AN was added as sole carbon source to the growth medium; control flask with each carbon (DNB or AN) was uesd without inoculum. Both growth and degradation of DNB or AN were followed spectrophotometerically and HPLC respectively, in addition to $\mathrm{pH}$ change through the growth period (6 days), as shown in Figures 1 and 2. It is noticeable that, after a fermentation period of $48 \mathrm{~h}$ the color of medium of DNB became deep yellow. Both DNB and AN media became brown after $72 \mathrm{~h}$; then it became dark brown after 6 days. No changes were remarked in control flask. Conversion of DNB and AN to brown coloured oxygenated products was reported by Parris (1980). Polymerization of highly reactive catechol or protocatechute was reported also by Loidl et al. (1990) and Bachofer et al. (1975); it may give a reason for the accumulation of the brownish product.

From Figures 1 and 2, it was found that, in the expo- nential phase Corynebacterium sp. was active in the degradation of DNB and AN and it reached the stationary phase after $72 \mathrm{~h}$. Within $24 \mathrm{~h}$, about $50 \%$ of DNB and $30 \%$ of $A N$ were degraded. Then they were decreased to a minimum concentration after 6 days. In case of DNB degradation by Corynebacterium $\mathrm{sp}$, the $\mathrm{pH}$ values were decreased from 7.5 to 6.57 . This may be due to the presence of acidic oxygenated products while the $\mathrm{pH}$ of aniline degradation was found to be between $\mathrm{pH} 7$ and 7.4. Similar study was done by Yanase et al. (1992) and Liu et al. (2002) who mentioned that phenol was degraded optimally at $\mathrm{pH} 8$.

\section{Effect of yeast extract on the degradation of AN and DNB}

Yeast extract contains important growth factors for the growth of the bacterium and nitrogen source. Different concentrations of yeast extract ( 0 to $5 \mathrm{~g} / \mathrm{l})$ were tested for studying their effects on DNB and AN degradation as shown in Figures 3 and 4 . After $48 \mathrm{~h}$, the cells growth was determined spectrophotomatrically, while the residual and products were determined by HPLC. At concentration of 2-5 g/l yeast extract, good growth of Corynebacterium sp. was determined, in addition to the degradation of $\mathrm{DNB}$ and $\mathrm{AN}$; and the intermediate protocatechuic acid formation increased.

\section{Optimum concentration of AN and DNB for their degradation}

Different concentrations of aniline or DNB ranged from 

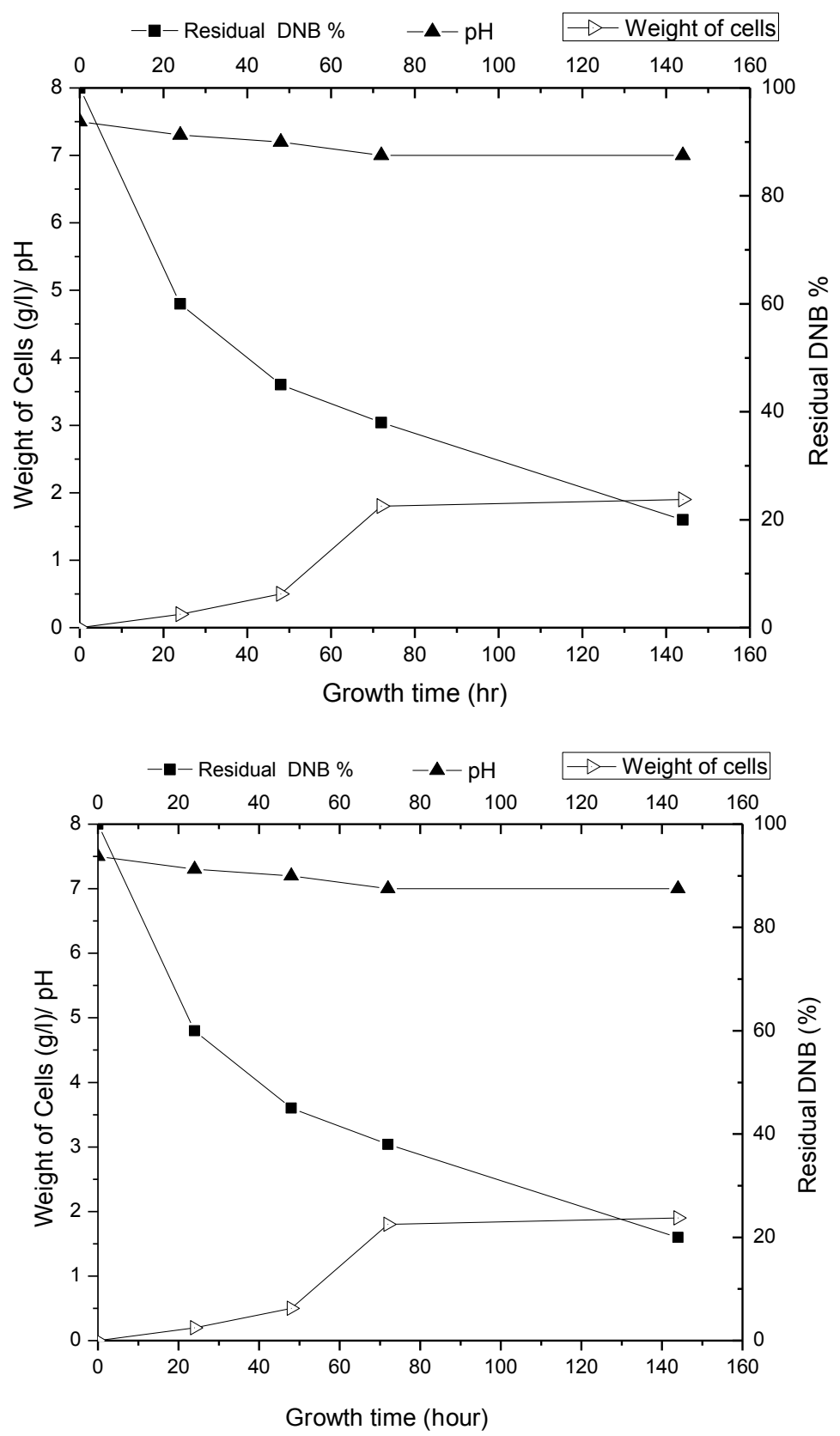

Figure 1. The relationship between the Corynebacterium sp. growth time and DNB degradation.

0.5 to $5 \mathrm{~g} / \mathrm{l}$ as sole carbon sources were tested. The products were determined after $48 \mathrm{~h}$ by HPLC as shown in Figures 5 and 6 . At concentration of $2.5-5 \mathrm{~g} / \mathrm{l}$ of $\mathrm{AN}$ or DNB, no significance changes in their concentrations were detected in addition to their inhibition in the cells growth. Good growth was observed at concentrations from 0.5 to $1 \mathrm{~g} / \mathrm{l}$ of AN and DNB as shown in Figures 5 and 6; maximum concentration of protocatechuic acid of 80 and $99 \%$ could be detected at concentration of $0.5 \mathrm{~g} / \mathrm{l}$ of AN and DNB, respectively.

\section{Ring cleavage enzyme}

In order to find the initial pathway for degradation of DNB and AN by Corynebacteria sp. two key catalyzing enzymes, catechol 2,3 dioxygenase and catechol 1,2dioxygenase, were assayed by using chatechol and protocatechuic acid as substrates.

Table 2 shows the specific activities of the enzymes extracted from the different kinds of cells grown with AN, DNB or glucose as the only carbon source in the medium. 


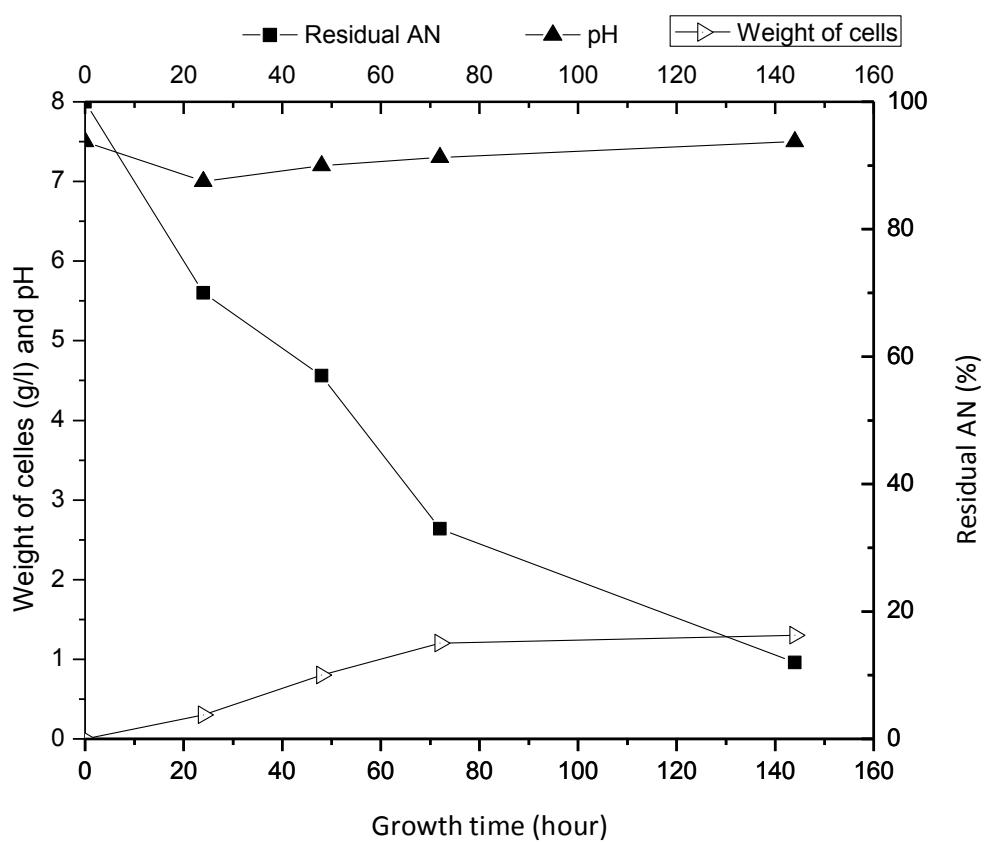

Figure 2. The relationship between the Corynebacterium sp. growth time and aniline degradation.

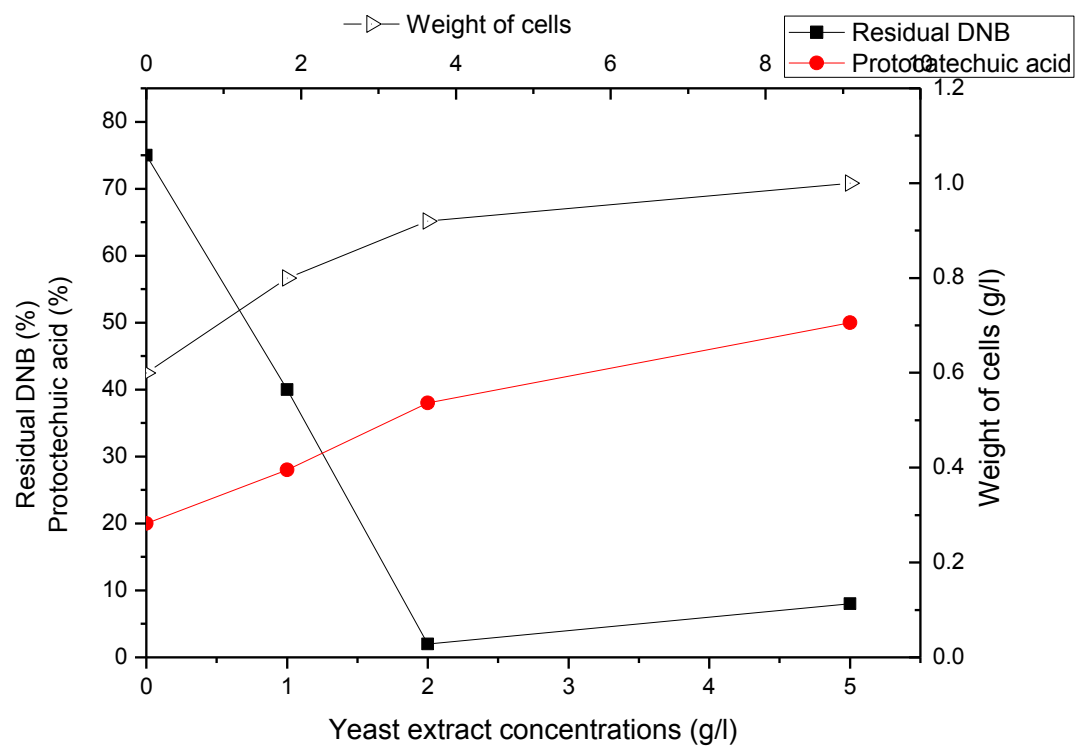

Figure 3. Effect of yeast extract concentration on the DNB degradation.

The cells grown on both AN and DNB showed high catechol 1,2 dioxygenase activity while no activity of catechol 2,3 dioxygenase was detected. Significant activity of catechol 1,2-dioxygenase was found only in the cells grown on medium containing AN or DNB. These results suggest that an ortho cleavage pathway may be present in this strain. Contrary to our results, Bae et al.
(1996) and Liu et al. (2002) found that the degradation of aniline goes through meta cleavage; also, Mulla et al. (2011) found that Micrococcus sp. strain SMN-1 degraded 2-nitrotoluene through 3-methylcatechol by a meta-cleavage pathway, with release of nitrite. The results are in agreement with the results of Loidl et al. (1990) and Sutherland et al. (1981) who found that aniline 


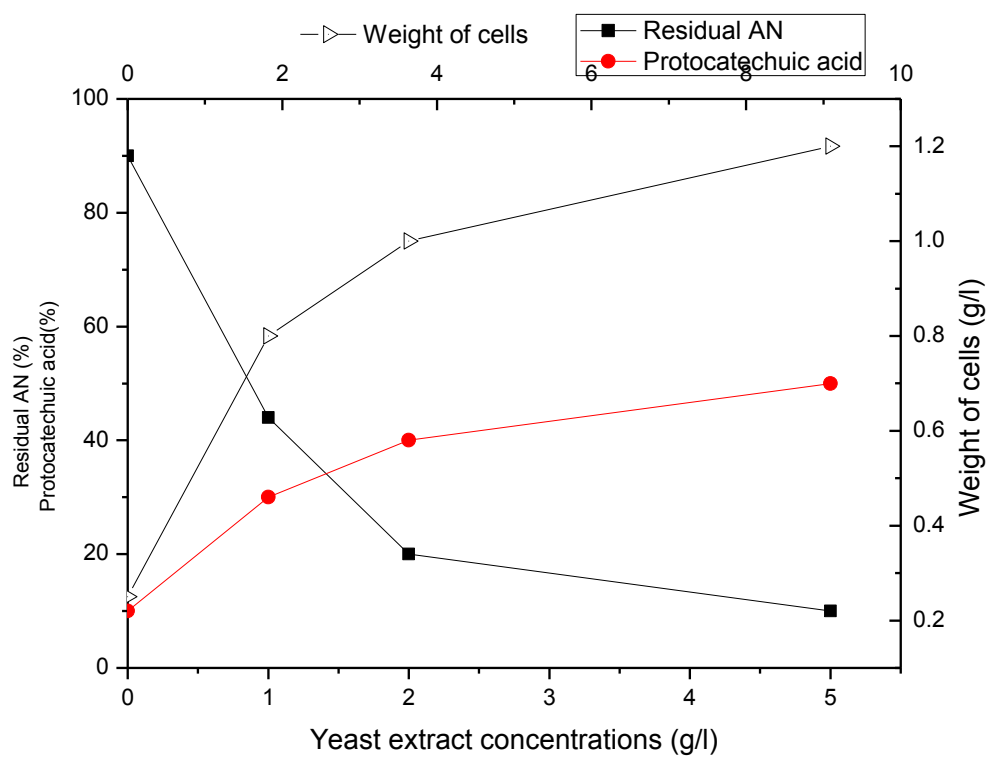

Figure 4. Effect of yeast extract concentration on the aniline degradation.

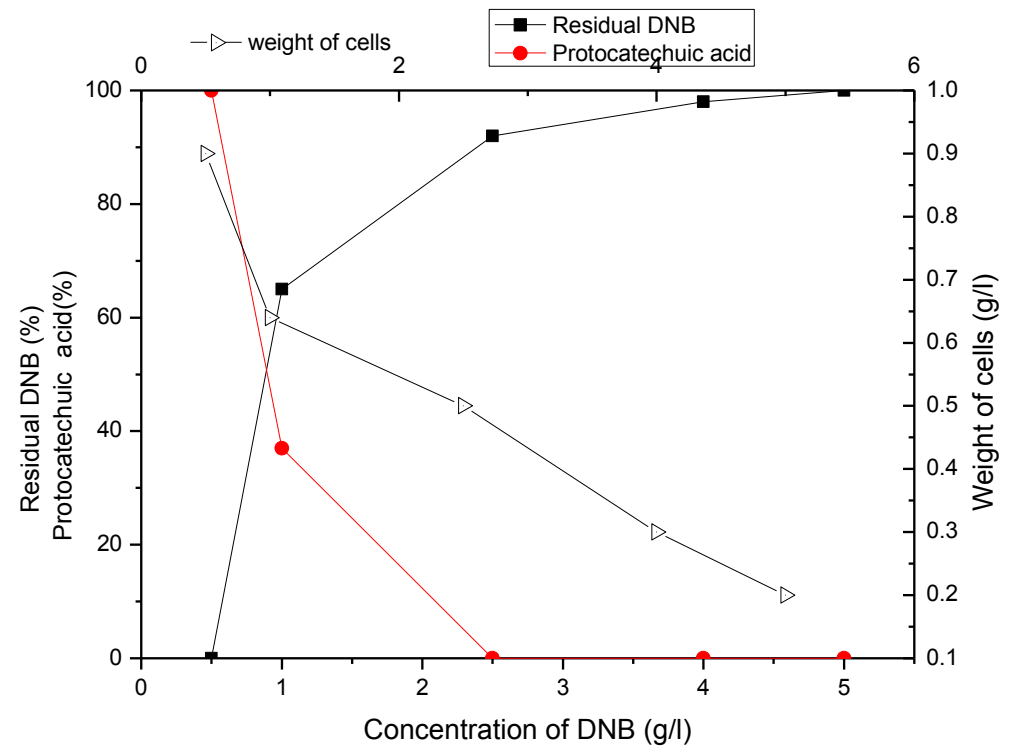

Figure 5. Effect of different DNB concentrations on the Corynebacteium sp. growth and protocatechuic acid production.

and benzoic were degraded via ortho pathway.

A new UV spectrum at $257 \mathrm{~nm}$ which may be $\beta$-carboxy -muconate was detected in enzyme reaction products of protocatechuic acid as substrate with catechol 1,2dioxygenase enzyme (Ornston and Stanier, 1966). Then, the isolated strain Corynebacterium sp converted $\beta$ carboxy-muconate to $\beta$-ketoadipate which subsequently was cleaved to succinate and acetyl COA (Ornston and Stanier, 1966).

\section{Conclusion}

A Corynebacterium sp, which could utilize dinitrobenzoic acid and aniline as the sole carbon source, was isolated from the soil. The growth of this organism was optimum at a concentration of 0.5 to $1 \mathrm{~g} / \mathrm{l}$ of either aniline or DNB where protocatechuic acid appeared in appreciable amounts in the media. The optimum concentration of yeast extract was $2 \mathrm{~g} / \mathrm{l}$. Catechol 1,2-dioxygenase was 


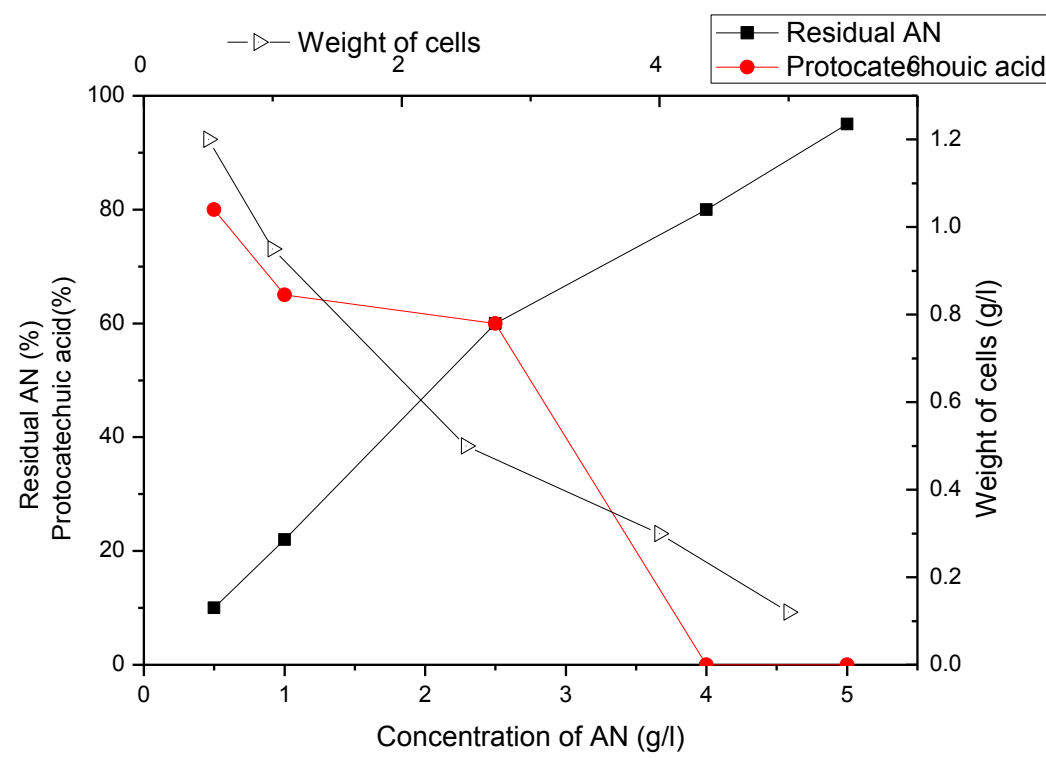

Figure 6. Effect of different aniline concentrations on the Corynebacteium sp. growth and protocatechuic acid production.

Table 2. Specific enzyme activities in cell extracts of Corynebacterium sp. growen in DNB or aniline.

\begin{tabular}{|c|c|c|c|c|}
\hline \multirow{3}{*}{ Enzyme assayed } & \multirow{3}{*}{ Substrate } & \multicolumn{3}{|c|}{ Grown substrate } \\
\hline & & Glucose $(\mathrm{U} / \mathrm{mg})$ & DNB (U/mg) & Aniline $(\mathrm{U} / \mathrm{mg})$ \\
\hline & & \multicolumn{3}{|c|}{ Specific activities $^{*}$} \\
\hline \multirow{2}{*}{ Chatechol 2,3-dioxygenase } & Chatechol & 0 & 0 & 0.04 \\
\hline & Protocatechute & 0.01 & 0 & 0.01 \\
\hline \multirow{2}{*}{ Chatechol 1,2-dioxygenase } & Chatechol & 0.02 & 67.0 & 48.0 \\
\hline & Protocatechute & 0.0 & 50.0 & 37.0 \\
\hline
\end{tabular}

Specific activities: Units per gram protein $(\mathrm{U} / \mathrm{mg})$.

found to be inducible enzyme, in cells grown aniline or DNB. These results indicate that the degradation of aniline or DNB was effected via ortho cleavage pathway.

\section{ACKNOWLEDGEMENT}

The authors acknowledge Biochemistry Department, Faculty of Science, King Abdulaziz University, Jeddah for the technical support.

\section{REFERENCES}

Asturias JA, Timmis KN (1993). Three different 2,3 dihydroxybiphenyl1,2- dioxygenase genes in the gram-positive polychlorobiphenyldegrading bacterium Rhodococcus globerutus P6. J. Bacteriol. 175:4631-4640.

Bachofer R, Lingens F, Schfer W (1975). Conversion of aniline into pyrocatechol by Nocardia sp. Incorporation oxygen-18. FEBS Letter 50:288-290.

Bae HS, Lee JM, Kim YB, Lee ST (1996). Biodegradation of the mixtures of 4- chlorophenol and phenol by Comamonas testosteroni
CPW301. Biodegradation 7:463-469.

Bengtsson G, Carlsson C (2001). Contribution of suspended and sorbed ground water bacteria to degradation dissolved and sorbed aniline. Appl. Microbiol. Biotechnol. 57:234-41.

Dorn E, Knackmuss II (1978). Chemical structure and biodegradability of halogenated aromatic compounds; substituent effects on 1,2 dioxygenation of catechol. Biochem. J.174:85-94.

Haigler BE, Wallace WH, Spain JC (1994) Biodegradation of 2nitrotoluene by Pseudomonas sp. strain JS42. Appl. Environ. Microbiol. 60:3466-3469.

Huang Y, Zhao KX, Shen XH, Chaudhry MT, Jiang CY, Liu SJ (2006). Genetic characterization of the resorcinol catabolic pathway in Corynebacterium glutamicum. Appl. Environ. Microbiol. 72:72387245.

Lechevaller MW, Seider RJ, Evans TM (1980). Enumeration and characterization of standerd plate count, bacteria in chlorinated and raw water supplies. Appl. Environ. Microbiol. 40:922-930.

Lee SY, Le TH, Chang ST, Park JS, Kim YH, Min J (2010). Utilization of phenol and naphthalene affects synthesis of various amino acids in Corynebacterium glutamicum. Curr. Microbiol. 61:596-600.

Liu Z, Yang H, Huang Z, Zhou P, Liu SJ (2002). Degradation of aniline by newly isolated, extremely aniline-tolerant Delftia sp. AN3. Appl. Microbiol. Biotechnol. 58:679-82.

Loidl M, Hinteregger C, Ditzelmüller G, Ferschl A, Steichsbier F (1990). Degradation of aniline and monochlorinated anilines by soil-born Pseudomonas acidovorans Strains. Arch. Microbiol. 155:56-61. 
Lowry OH, Roseberough ALF, Randall RJ (1951). Protein measurement with the folin phenol reagent. J. Biol. Chem. 193:265- 275.

Marvin-Sikkema, FD, de Bont JA (1994). Degradation of nitroaromatic compounds by microorganisms. Appl. Microbiol. Biotechnol. 42:499507.

Mulla SI, Hoskeri RS, Shouche YS, Ninnekar HZ (2011). Biodegradation of 2-Nitrotoluene by Micrococcus sp. strain SMN-1. Biodegradation 22:95-102.

Nishino SF, Spain JC (2004). Catabolism of nitroaromatic compounds. In: Rams J-L (ed) Pseudomonas.Kluwer Academic/Plenum Publishers, New York, NY. 3:575-608.

Nishino SF, Spain JC (2006). Biodegradation of 3-nitrotyrosine by Burkholderia sp. strain JS165 and Variovorax paradoxus JS171. Appl Environ Microbiol 72:1040-1044.

Ornston LN, Stanier RY (1966). The conversion cahtechol and Protocatechuate to $\beta$-Ketoadipate by Pseudomonas Putida. J. Biol. Chem. 241:3776-3786.

Parris GE (1980). Environmental and metabolic transformation of primary aromatic amines and related compounds In: Gunther FA(ed) Residue reviews. Springer, Berlin Heidelberg New York, 76:1-30.

Peres CM, Agathos SN (2000). Biodegradation of nitroaromatic pollutants:from pathways to remediation. Biotechnol. Annu. Rev. 6:197-220.

Puntus IF, Filonov AE, Kosheleva IA, Gayazov RR, Karpov AV, Boronin AM (1997). Isolation and characterization of microorganisms degrading polycyclic aromatic hydrocarbons. Micobiology 66:222225.
Samanta SK, Bhushan B, Chaushan A, Jain RK (2000). Chemotaxis of a Ralstonia sp. SJ 98 toward different nitroaromatic compounds and their degradation. Biochem. Biophys. Rescommun. 269:117-23.

Shen X H, Zhou NY, Liu SJ (2012). Degradation and assimilation of aromatic compounds by Corynebacterium glutamicum: another potential for applications for this bacterium?. Appl. Microbiol. Biotechnol. 95:77-89.

Shen XH, Jiang CY, Huang Y, Liu ZP, Liu SJ (2005). Functional identification of novel genes involved in the glutathione-independent gentisate pathway in Corynebacterium glutamicum. Appl. Environ. Microbiol. 71:3442-3452.

Shen XH, Liu ZP, Liu SJ (2004). Functional identification of the gene locus ncg12319 and characterization of catechol 1,2-dioxygenase in Corynebacterium glutamicum. Biotechnol. Lett. 26:575-580.

Sutherland JB, Crawford DL, Pometto AL (1981). Catabolism of substituted benzoic acids by Streptomyces Sp. Appl. Environ. Microbiol. 41:442-448.

Walia SK, Ali-Sadat S, Rasul Chaudhary G (2003). Influence of nitro group biotransformation of nitrotoluenes in Pseudomonas putida OU83. Pestic Biochem. Physiol. 76:73-81.

Won WD, di Salvo LH, Ng L (1976). Toxicity and mutagenicity of 2,4,6trinitrotoluene and its microbial metabolites. Appl. Environ. Microbiol. 31:576-580.

Yanase H, Zuzan K, Kita K, Sogabe S, Kato N (1992). Degradation of phenols by thermophilic and halophilic bacteria isolated from a marine brine sample. J. Ferment. Bioeng. 74:297-100. 